\title{
Alvar Aalto and Álvaro Siza: The Link between Architecture and Nature in the Construction of Place
}

\author{
By Catarina Gomes Sampaio*
}

\begin{abstract}
The link between architecture and nature, from the standpoint of the relation of architecture with its place and, in a broader sense, with the landscape it integrates, is one of the main concerns explicit in Alvar Aalto's and Álvaro Siza's design processes, works and writings. We propose to explore it as an existing parallelism between both architects' practices and as a problem whose understanding has a constancy in each one's career related both to their methodological approach and to their continuous postponement of the theoretical systematization of their convictions. Aalto and Siza seek a cohesive balance between man's interventions and pre-existing nature. For both, architecture is something that contrasts with nature by alterity, but that also adapts and complements it. The relation with place and landscape has a propellant role in their design processes, enhanced by their distrust of an a priori theory. Their projects are born from the place they simultaneously define by a pondered search, developed case by case, for naturalness, for the same sense of evidence, proportion and simplicity they find in nature. Therefore, we explore the use they make of conceptual analogies with nature's formative processes, and even of formal analogies with the surrounding nature, which Bruno Zevi considered the naturalist misconception of organic architecture. To better understand and relate Aalto's and Siza's approaches to the problems outlined, a comparison was made with other architects whenever relevant, like Le Corbusier and Aldo Rossi, whose practices and positions towards project theory are thought to be distinctive.
\end{abstract}

Keywords: Alvar Aalto, Álvaro Siza, theory, methodology, place, nature, alterity, complementarity, analogy.

\section{Architecture and Nature}

From its more ancestral meaning, nature refers to the origin or spring from which everything is born or arises, as well as to the spontaneous formative process and to everything that its strength creates and forms.

Nature is, therefore, matter, cause and action, which stand out before human consciousness. It is the world, man first compared with, in an inevitable search to demarcate its own field of action.

However, man's actions and conceptions, being a result of his inevitable relation to the environment around, integrate nature's order as part of it, that is,

${ }^{*}$ PhD Student, Faculty of Architecture, University of Porto (FAUP), Portugal and Researcher, FAUP Architecture and Urbanism Study Centre (CEAU), Group: Architecture: Theory, Project and History, Portugal. 
as a subsequent part of its driving stimulus, materialized by man's conscientious and responsible capacity to create.

When understood this way, every man's work is a second nature or, in Alvar Aalto's words (1963, p. 158), 'the manmade extension of nature', whose capacity to convince us of its rightness is the bigger the closer it is to the naturalness and the evidence which characterize the former.

'Once created, every work of art, good or bad, is part of nature. The antiquity is part of nature, and when it thrills us, it is part of the more natural nature' (Goethe, n.d., p. 284).

Therefore, according to the architect Antonio Monestiroli, throughout history, art, and within it architecture, imitated nature 'from the simple reproduction of natural forms, to the more complex analogy between the artistic construction and the construction of nature'. But art also imitated itself, 'based on the idea that there should be an artistic form of reference (...) and, therefore, based on the concept of historical continuity of the artistic achievement' (Monestiroli, 1993, p. 193). Resorting to a pre-existing formal world built by man, enables architects to circumvent the direct analogy with nature, avoiding naturalism. But it also tends to a formal conventionalism, that the analogy with nature makes possible to renew (Monestiroli, 1993, pp. 204205). Nature and history are, thus, the two complementary terms of reference for architecture.

Nevertheless, what art permanently searches for is nature's naturalness. Even when the architects resort to the analogy with past artistic works and not directly with nature, what they seek is the way those works achieved the same evidence of nature. Thus, resorting to history is an indirect way of resorting to nature. Naturalness in art, is sought both by the direct analogy with nature's formative processes, which occasionally leads to the imitation of its forms too, and by the summoning or even reproduction of past artistic achievements that get close to what Álvaro Siza (1983a, p.29) called 'the singularity of the evident things'.

The search for naturalness, for this close link between nature and man's creations is one of the design problems to which the architects Alvar Aalto and Álvaro Siza give higher importance in their works. In this paper, we will explore it from the standpoint of the relation of architecture with its site, which is one of the main concerns explicit in their design processes, works and writings. We propose to recognize it as an existing parallelism between both architects' practices and as a problem whose understanding has a constancy in each one's career related both to their methodological approach and to their continuous postponement of the theoretical systematization of their convictions.

Whenever relevant, to better comprehend and relate Aalto and Siza understandings concerning the problem outlined, we will compare them with those of other architects whose practices and positions towards architectural design theory are thought to be distinctive, like Le Corbusier - from a previous 
generation, but close to the one of Aalto - and Aldo Rossi - from Siza's generation.

\section{The Link between Architecture and Nature in the Construction of Place}

In their search for an evident way of relating their works with the site in which to intervene, Aalto and Siza resort to analogy with nature, but also, as discussed by Monestiroli, with those they consider the more wisely designed constructions of the history of architecture, for their naturalness, order, coherence, proportion and simplicity.

They seek to construct a place, granting identity to the site, or else, to emphasize and retrieve its already existing distinctiveness, i.e., the peculiar character of place that by nature's and/or man's work the site already has, being identifiable within the surrounding context.

However, unlike the rationalist architects, as Le Corbusier and Aldo Rossi, who search in nature and past architectural achievements basis for the formulation of a design theory, after which to conceive their works, Aalto and Siza face the site without an a priori theory. They find in the site to intervene the circumstantiality from which their design processes arise, as they believe it happens in nature's way of building itself. Inputs from memories, culture, traditions and history knowledge emerge from their subconscious in the course of their design process. But those inputs are not part of a pre-established design theory. Their projects are born from the site they simultaneously define seeking for a cohesive balance between man's interventions and pre-existing nature. They design an architecture that contrasts with nature by alterity, but that also complements it, emphasizes it and seizes its naturalness recreating not only its processes, but also, sometimes, its forms. We will explore in this paper their approach from three different perspectives: the relation of alterity and complementarity between architecture and nature; the search for naturalness in architecture by conceptual analogy with nature formative processes; the formal analogy with nature forms which Bruno Zevi considered the naturalist misconception of organic architecture.

\section{Alterity and Complementarity between Architecture and Nature}

In one of his first texts, Siza referred to the ancient chapel built on a rocky outcrop between land and sea, close to the site of the Boa Nova Tea House, in Leça da Palmeira, Portugal (1958-1963) (Figure 1). He considered it exemplary due to the 'free and natural way it becomes part of the landscape' (Siza, 1964). This chapel - like the ancient Finnish architectures lauded by Aalto (1921; 1922) -, integrates the landscape with a 'simplicity', Siza, at the time, recognized to be rare and difficult, but necessary to rediscover; a simplicity that comes from the sensitive relation of alterity and complementarity that it sets with the place. 
Figure 1. Boa Nova Chapel and Siza's Tea House (1958-1963), at Leça da Palmeira, Portugal

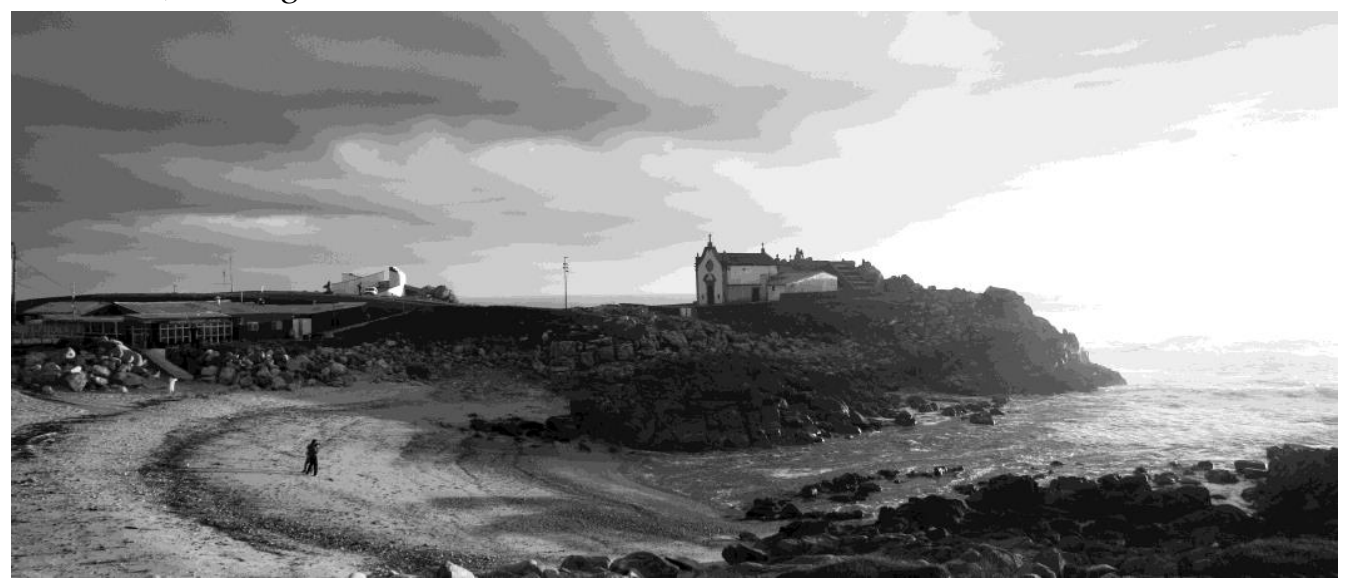

Photograph by Sampaio, C. (2014)

Relating their works with the place and landscape in which to intervene, Aalto and Siza do not disregard the classic and rationalist gesture of emphasizing the contrast between nature and man's creations, through the abstraction of geometric figures, from what Le Corbusier's Villa Savoye, at Poissy, France (1928-31), is one of the best examples. It comes, in Aalto's case, from his first neoclassic works and his later interest in the central European modern movement; and in Siza's case, from his academic background.

Nevertheless, they tend to soften this alterity between architecture and nature, detaching themselves from the rationalist architects, by: 1) the complete adaptation of their works to the particularities of the place in which to intervene, searching for a geometric order in the specific aspects of the close reality (Figure 2); 2) the intentional use of plants, such as trees and creepers along walls, that on the one hand, punctuate and help to clarify by contrast the built work, but on the other hand, 'soften the violence of light and forms' (Siza, 1995a), naturalizing the geometric volume and incorporating it into the surroundings (Figure 3); 3) emphasizing and/or reproducing morphological characteristics of the place in which to intervene through formal analogy - a theme developed later in this paper (Figure 4). 
Figure 2. Aalto's Muurame Church, Finland (1926) on the left $\mid$ Siza's Quinta da Conceição Swimming Pool at Leça da Palmeira, Portugal (1958-1965) on the right
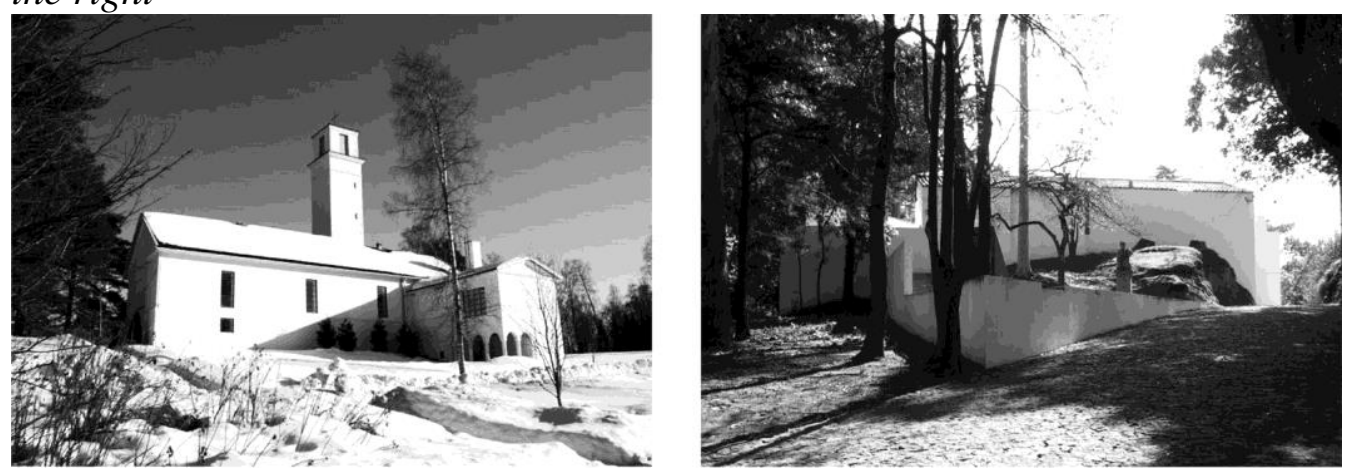

Photographs by Sampaio, C. (2012)

Figure 3. Aalto's Own House at Helsinki, Finland (1934-1936), on the left | Siza's Terraços de Bragança Residential Buildings at Lisbon, Portugal (19912004), on the right
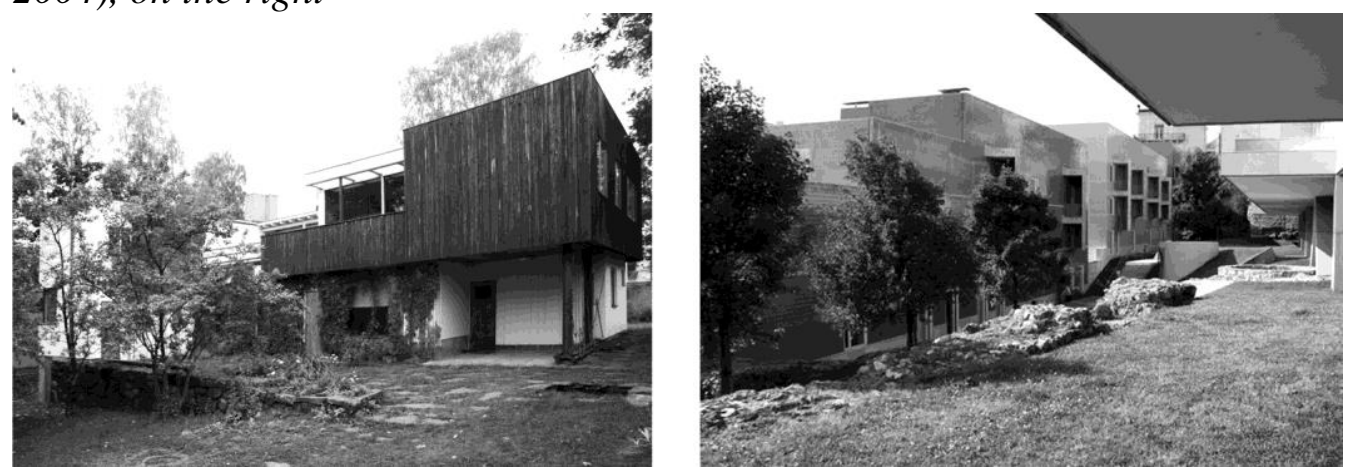

Photographs by Sampaio, C. $(2007 ; 2014)$

Figure 4. Aalto's 'Lappia' Radio Building and Theatre, at Rovaniemi, Finland (1969-1975), on the left | Siza's proposal model to the House of Architecture, at Matosinhos, Portugal (2007-...), on the right
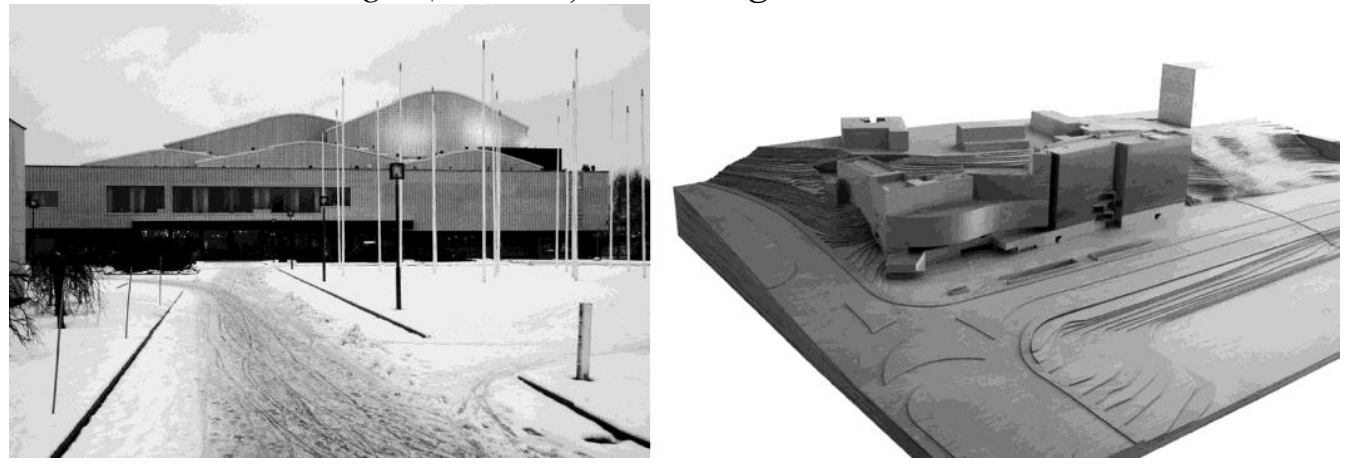

Photographs by Sampaio, C. $(2007 ; 2012)$

According to Siza, 'architecture, construction made by man, geometry, rigor, etc., are always in an organic connection with the landscape' (Siza, 1993, p. 17). Being the art of constructing or re-qualifying a place, 'architecture does not end at any point, it goes from the object to the space and, as a consequence, 
to the relation between spaces, to the encounter with nature' (Siza, 1998a, p. 19). This 'relation between nature and construction is decisive in architecture' he stated (Siza, 1998a, p. 5).

'Generally', he said, 'architecture detaches itself from nature, exactly because it needs to be different to exist, it does not detach itself by turning its back, but it is born from nature and it needs to distinguish itself from that in order to establish the wise frontiers for its elaboration'. (Siza, 1993, p. 17)

Siza believes that 'this alterity is essential to the design conception' (Siza, 1998a, p. 9). For him, architecture and, therefore, the city, need nature as a distinctive, but also complementary entity with which to relate: 'Nature and Art in continuity and rupture' as he defined it (Siza, 1995a).

Like a building related to the nearby nature, the city that extends and finds its limits in nature, establishing a relationship of continuity and complementarity with it, has an identity. It is different from others more and more similar to each other, which do end at any point, but are rather characterized by the constant growing and stretching of the construction to the horizon (Siza, 1995b; 1998a, p. 9).

Oporto is one of the cities that Siza likes the most for its distinctiveness. There, as he points out, the rugged topography 'for centuries repelled hasty urban plans' and received in a natural way 'as no manual could propose' the buildings where the terrain allowed (Siza, 1998b, p. 201).

Siza also refers several times to the cities of Portuguese foundation and especially to Rio de Janeiro. Those cities are encrusted in rough places 'chosen with ancient wisdom' where there is no need to build everything: 'what Nature gives does not need to be made' (Siza, 1988a, p. 51). Orography gives meaning and identity to the city whose contours are adapted to the topography and whose buildings are born from the complex relation of complementarity and counterpoint with the place; 'what is being built closely coexists with nature', shaping the landscape as a whole. There, 'above all, nothing is continuous, or closed, or systematic' (Siza, 1988a, p. 52). It results from an intuitive way of building that, as Siza wrote, 'does not explain or teach', that is not therefore deductible in a theory, but whose continuous design research, work after work, is necessary and urgent (Siza, 1988a, p. 52).

Aalto was never as clear as Siza in describing the symbiosis between nature and man-made forms he appreciated and searched for when designing his buildings. Not even in his writings from the twenties, when he intensely discussed this topic influenced by his interest in the Nordic Classicism and by his fascination with the hilltop towns of Tuscany.

But, he believed architecture 'should be placed in the landscape in a natural way, in harmony with its general contours', without following 'aesthetic norms' (Aalto, 1925a, p. 21), but rather a 'higher law...' (Aalto, 1924), not possible to be translated in a theory, but only procurable through 
what he called 'a natural sensitivity for beauty' (Aalto, 1925a, p. 21), i.e. through art and intuition.

'There is but one rule that holds in architecture: build naturally', stated Aalto (1925b, p. 18): build as nature does.

'Developing a project is to overcome the eternal opposition between nature and man's creation', further explained Siza (2005). 'Everything should come unavoidably evident': like in nature's constructions.

\section{Conceptual Analogy: The Sense of Naturalness in Architecture}

According to Aalto and Siza, although architecture most contrasts with nature by alterity, it finds in nature the source for its formulation. It refers to another aspect of the relation between architecture and nature: the use of conceptual analogies with nature formative processes in their architectural practices, which for both is enhanced by a visual, sensorial and emotional apprehension of the reality, understood and internalized through drawing.

Aalto and Siza seek to discover a gist they consider not deducible in a rational process in the way nature forms itself. In their design practices, the search for naturalness and evidence, i.e. for simplicity, for fair proportion, and for the ability to reconcile opposites constructing a harmonious whole is mainly guided by memory, by experience and by intuition.

Also the rationalists - like Le Corbusier and Aldo Rossi - consider nature a system of reference for their works. According to Le Corbusier (1966, p. 56), 'a sovereign determinism illuminates nature creations, in our eyes, and gives us the safety of a thing which is balanced and rationally done, of a thing infinitely modulated, evolutive, varied and unitarian'. A thing whose intelligibility and poetic quality he tries to achieve in his architecture. However, for him, unlike Aalto and Siza, the poetic quality of nature comes from a system rationally deducible in a theory and in sequences of harmonious proportions that inform the geometry, which is explicit in his studies about Le Modulor.

Rossi, in his A Scientific Autobiography (1981, p. 5), confessed he feels 'attracted by stasis and naturalness, by the classicism of architecture and by the naturalism of people and objects. (...) In all of my projects and drawings, I believe there may be a hint of this naturalism which transcends their oddities and defects'. But, as Le Corbusier, he has a rationalistic conviction. In a text about Étienne-Louis Boullée, Rossi stressed the importance of building a theory, a 'logical system, valid in itself', 'common to all works conceived, designed or built that we know (...) to, thereby, try to answer all the problems man and civil progress put to architecture' (Rossi, 1967, pp. XXVIII-XXIX). Furthermore agreeing with Boullée's proposition that simplicity in architecture results from the adhesion of the work to the laws of nature, Rossi pointed nature as a source of this system. This way, he concluded, 'classic architecture which was born from an a priori idea, closed in a geometric thought, returns to nature; has therefore the value of a natural thing'. Something that, in his view, 
'no organic adjustment of forms can achieve' (Rossi, 1967, pp. XXXVIXXXVII).

Both Le Corbusier and Rossi seek to extract from nature rational principles and compositional logics through which they believe to be possible to formulate a transmissible system, a theory, capable of serving as a basis for architectural work.

On the contrary, Aalto's and Siza's design practices do not start from a systematical theory. Their theoretical views are built work by work, theme by theme, through partial and fragmented approaches, which they never come to systematize because, as Siza (1978, p. 36) said, 'from one place to another everything is very different, very complex' to allow a systematic design approach.

Thus, both tend to an organicist understanding of architecture that Adolf Behne (1926) called functionalist and opposed to the rationalist.

According to Behne, the 'rationalist' - like Le Corbusier - 'seeks the most conformity to distinctive situations, (...) the most possibly adjusted to the general needs, the norm' (Behne, 1926, p. 72). 'His way of thinking proceeds from the wholeness to particularity' (Behne, 1926, p. 66).

While, the organicist, or in Behne words 'the functionalist', - like Aalto and Siza - 'wants the most absolutely adjusted, the unique in each concrete situation' (Behne, 1926, p. 72). The organicist understands that each project needs a different approach adapted to the unfinished nature that, case by case, he has to complete. So, he gives to the character of the place a propellant role in the specificity of each project. 'For him, the ideal building would grow from the soil like an organic plant', because he considers 'construction not as a volume stranger to nature, but rather as one of its organic components', (Behne, 1926, p. 62). Thus, besides the compliance with nature formative processes, the organicist, unlike the rationalist, also tends 'to make the building participate, by a sort of mimesis, in the existence of living organisms' (Behne, 1926, p. 69), falling in what Bruno Zevi (1950, p. 73) considered to be the naturalistic fallacy of organic architecture: 'through saying that we must keep our eyes on nature there is a danger of a mistaken belief that we ought to imitate nature'. In Zevi's view organic architecture resorts to the analogy with the way nature forms itself, but not with its shapes.

\section{Formal Analogy with Nature in Architecture}

Zevi trusted the purity of the functional justifications given by Aalto for his works (Zevi, 1950, p. 60). He did not recognize in them the 'halo of a romantic naturalism, of a mechanical return to nature' he disapproved in organic architecture (Zevi, 1950, p. 73). Nevertheless, Aalto's naturalistic side is evident, for instance: in the Savoy vases from 1937, in whose contours Siza (1998c, p. 211) saw with fascination an allusion to "the curves of lakes in Finland'; and at the M.I.T. Senior Dormitory, in Cambrigde, United States (1947-1948), whose winding façade evokes the upstream sinuosity of the river in front of it. 
Actually, as already mentioned above in this paper, Aalto and Siza resort to the analogy with the forms of living and inert nature, to soften the geometric abstraction of the figures their quest for ensuring architecture alterity with nature generates. They reproduce in their buildings metaphorical references of the site for which they are designed, or else the ones that it evokes, in an attempt to naturalize their works.

Among the multiple forms and textures that formally approach Aalto's Villa Mairea, in Noormarkku, Finland (1937-39), to the pine forest around it, there are the columns composed of sets of poles tied with rattan that support the porch, the organic forms of the pool, the entrance canopy, the volume of the studio and the verticality of the wooden slats lining its exterior walls, as well as the two divergent poles which apparently support it and whose configuration resembles, as Richard Weston (1995, pp. 88-90) proposed, the birch trees whose trunks generally forks, commonly existing in the edges of the Nordic pine forests.

At the Helsinki House of Culture, Finland (1955-58), Aalto divided the program in two volumes which relate to the dual character of the surroundings by their configuration: the rounded volume of the concert hall evokes the organic nature of the adjacent park; while the orthogonal volume of offices seeks a parallel with the desired regularity of what, at the time, was already a residential area formed by low wooden buildings which came to be replaced by banal high-rise apartment blocks.

At the Finlandia Hall, in Helsinki, Finland, (1962-71), built in a park on the Töölönlahti lakeshore, Aalto worked out the relation of the building with the cityscape and designed it as a rocky formation, similar to the ones that in a smaller scale outcrop from its surroundings. Like a rock that reveals in its fissures the efforts undergone since its origin, the big white building lined with Carrara marble seems to result from the cracking and vertical movement of blocks - as the prismatic or columnar disjunction of the basalt, for instance - in a quest for the evidence of its functional program (conferences and artistic performances hall) and for an appropriate continuity with the surroundings. Seen from the opposite shore of the lake, the volume of the auditorium rises in the landscape and relates to the tower of the National Museum designed by Herman Gesellius, Armas Lindgren and Eliel Saarinen (1902-1910), while the rest of the building characterized by its horizontal mass and vertical rhythm of the façade engages in a dialogue with the Parliament House planed by Johan Sigfrid Sirén (1924-1931), that stands out in the landscape with its colonnade. Seen from Southwest, the building standing at a lower level than the street that gives access to its main entrance is almost unnoticed, merging itself with the park differently according to the seasons. In winter, the white mantle of snow covering the park matches its marble finish. In the summer, the surrounding vegetation, apart from masking parts of its façade, blends chromatically with the green patina of the copper sloping roof of the auditorium.

In Siza's work, the Iberê Camargo Museum, in Porto Alegre, Brasil (19982008), for instance, echoes through its higher volume the cliff whose concavity it occupies. As a counterpoint to the geometric regularity of the façades that 
face directly the slope, the main façade of this volume evokes, by its undulation, the orographic organicity that involves it and the water movement of the river Guaíba in front of it. Besides, Siza divided the program in other non-orthogonal lower volumes that, like the little constructions complementary to the main body of Aalto's Summer House, in Muuratsalo, Finland (1953), refer to a natural or spontaneous disposition of things, to an informality, which Siza and Aalto believe to be inherent to the way nature precedes when its turn comes.

In Aalto and Siza design practices formal analogy with nature does not come from a vain reproduction of nature, or as quest to hide the works merging them with the surrounding context, but else from their subjective and autobiographical contribution when searching for the evidence and simplicity they find in nature.

\section{Conclusions}

In their quest for naturalness in architecture, Aalto and Siza relate their works with nature from three converging aspects already discussed in this paper: 1) the relation of alterity and complementarity between architecture and nature; 2) the conceptual analogy between the architectural practice and nature's formative process; 3 ) the formal analogy with nature in architecture sometimes intuitively used as the origin or the source of the architectural design process.

Unlike the rationalist architects, who seek naturalness mainly through the formulation of a design theory after which their works arise, Aalto and Siza, trust their artistic spontaneity as a starting and clarifying design tool. They tend to an intuitive and empirical design approach stimulated by artistic practices developed in parallel to the architectural process, which inform the design and unlock the mind when the solution to a specific problem hardly comes clear. Aalto painted, Siza draws continuously and occasionally, both did sculpture. Aalto plainly explained the contribution of these practices to architecture in a text Siza quoted, considering it a sharp description of the 'thinking process of designing' (Siza, 1983b):

'I forget the whole maze of problems for a while, as soon as the feel of the assignment and the innumerable demands it involves have sunk into my subconscious. I then move on to a method of working that is very much like abstract art. I simply draw by instinct, not architectural syntheses, but what are sometimes quite childlike compositions, and in this way, on an abstract basis, the main idea gradually takes shape, a kind of universal substance that helps me to bring the numerous contradictory components into harmony.' (Aalto, 1948, p. 108) 
According to Aalto, 'purity of form can only arise from a careful and highly developed artistic work' (1925c, p. 37). It is regrettable, he wrote, that the analytical trend of the modern western man progressively blurs human 'natural insight' and weakens his 'immediate receptiveness' (Aalto, 1925d, p. 57). In his view, 'architectural research can be more and more methodical, but the substance of it can never be solely analytical. Always there will be more of instinct and art in architectural research' (Aalto, 1940, p. 103). As he later clarified, 'our senses transmit to us the raw materials on which our thinking is based', even though, he warned, 'we must make sure that the world of the senses remains our servant, not vice versa' since, in architecture, the concepts of naturalness, evidence and clarity grasped by our senses can only be achieved by the synthesis between intuition and reason enhanced by the artistic practice (Aalto, 1947, p. 136).

Describing his design processes, Siza says they start from an 'immediate impression' (Siza, 1980a, p. 2), an 'emotion' (Siza, 1992) that arises from facing the site in which to intervene at a particular time, 'without an a priori idea, but only with an approximate knowledge of the program' (Siza, 1986). They are developed from an 'intuited idea' (Siza, 1988b, p. 53) in a first visit to the place (Siza, 1986), or, sometimes, even before visiting it and without knowing it profoundly, using only what is already known about it (Siza, 1983a, p. $27 ; 1991$, p. 59). From this intuition comes what Siza calls 'a subjective (imperfect, or incomplete) composition' (Siza, 1988b, p. 53), a picture 'that is never rigorous' (Siza, 1980a, p. 2), as it precedes the deep knowledge of the objectives and conditions to be considered in the course of a continuous and patient process, full of doubts, progresses and setbacks, where the initial idea is progressively informed, worked and tested through a compromise between intuition and rigorous verification, based on drawing.

Also Le Corbusier and Rossi recognized the subjective and autobiographical contribution of the architect when searching for the poetic dimension they found in nature. In Le Corbusier's words (1953, p. 11), 'painting, architecture, sculpture are a unique phenomena of plastic nature in the service of poetic research'. Rossi believes 'there is no art that is not autobiographical' (Rossi, 1967, p. XXXVI). Both of them painted and drew in parallel to their architectural practices. However, unlike Aalto and Siza, they depart from a rationalistic base to which they intend to return.

From an opposite standpoint, Aalto and Siza distrust the applicability of an a priori design theory. They consider the architectural work is not made from a 'sudden inspiration' (Siza, 1992), but it is thoroughly developed after it.

For them, naturalness, 'harmony cannot be achieved by any other means than art. (...) A harmonious result cannot be achieved with mathematics, statistics, or probability calculus' (Aalto, 1955, p. 174). There are no rules that can ensure it. Each site is different, 'each order is different, so we can not take solutions in a systematic way' (Aalto, 1967, p. 17). Constructing a place, (re)defining its identity, comes from what Siza called a 'second spontaneity, laboriously conquered' (Siza, 1987, p. 39), i.e. from a natural insight urge that is then profusely modulated until its materialization in a work they never 
consider completely finished, as perfection belongs to nature. It is, therefore, why both of them appreciate nature's action over their works correcting and improving design misconceptions, whether by the vibrant force of greenery smoothing architecture or by the naturalizing erosion process that arises from the inevitably passage of time.

'When entering our old churches, gazing at a Gustavian country manor or examining a century-old work of rural handicraft, we are seized by emotion. No doubt this is partly due to the trace of human handwork on the surface, the artistic purity of building materials or the simple lines adapted to our landscape; on the other hand, it also has to do with the signs of wear and centuries of patina in the building material.' (Aalto, 1922, p. 33).

This work is funded by FEDER Funds through the Operational Programme for Competitiveness Factors - COMPETE and National Funds through FCT Foundation for Science and Technology within the project «PEstC/EAT/UI0145/2011».

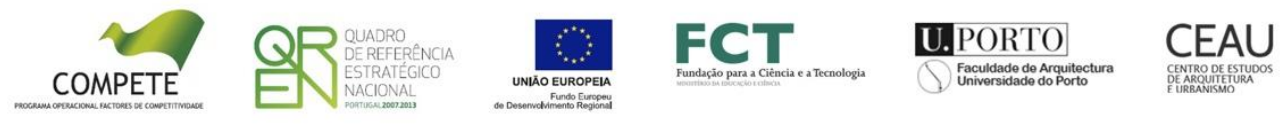

\section{Bibliography}

Aalto, A., 1921. Our Old and New Churches. In: G. Schildt, ed. 1997. Alvar Aalto in his own words. New York: Rizzoli. pp. 35-37.

Aalto, A., 1922. Motifs from Past Ages. In: G. Schildt, ed. 1997. Alvar Aalto in his own words. New York: Rizzoli. pp. 32-35.

Aalto, A., 1924. The Hilltop Town. In: G. Schildt, ed. 1997. Alvar Aalto in his own words. New York: Rizzoli. p. 49.

Aalto, A., 1925a. Architecture in the Lanscape of Central Finland. In: G. Schildt, ed. 1997. Alvar Aalto in his own words. New York: Rizzoli. pp. 21-22.

Aalto, A., 1925b. Temple Baths on Jyväskylä Ridge. In: G. Schildt, ed. 1997. Alvar Aalto in his own words. New York: Rizzoli. pp. 17-19.

Aalto, A., 1925c. Finnish Church Art. In: G. Schildt, ed. 1997. Alvar Aalto in his own words. New York: Rizzoli. pp. 37-38.

Aalto, A., 1925d. Abbé Coignard's Sermon. In: G. Schildt, ed. 1997. Alvar Aalto in his own words. New York: Rizzoli. pp. 56-57.

Aalto, A., 1940. The humanizing of Architecture. In: G. Schildt, ed. 1997. Alvar Aalto in his own words. New York: Rizzoli. pp. 102-107.

Aalto, A., 1947. The Dichotomy of Culture and Technology. In: G. Schildt, ed. 1997. Alvar Aalto in his own words. New York: Rizzoli. pp. 136-137.

Aalto, A., 1948. The trout and the stream. In: G. Schildt, ed. 1997. Alvar Aalto in his own words. New York: Rizzoli. pp. 107-109. 
Aalto, A., 1955. Art and Technology. In: G. Schildt, ed. 1997. Alvar Aalto in his own words. New York: Rizzoli. pp. 171-176.

Aalto, A., 1963. Aims as SAFA Chairman. In: G. Schildt, ed. 1997. Alvar Aalto in his own words. New York: Rizzoli. pp. 157-164.

Aalto, A., 1967. Conversación con Göran Schildt [Interview with Göran Schildt]. In: J. Pallasmaa, ed. 2010. Conversaciones con Alvar Aalto [Conversations with Alvar Aalto]. Barcelona: Editorial Gustavo Gili. pp. 15-28. [In Spanish]

Behne, A., 1926. III. Del espacio conformado a la realidad configurada. [From space shaped to configured reality]. In: J. A. Esquide, ed. 1994. 1923. La construcción funcional moderna. [Modern functional construction]. Barcelona: Ed. del Serbal. pp. 53-82. [In Spanish]

Goethe, n.d.. Maximes et Réflexions. [Maxims and Reflections]. In: Jean-Marie Schaeffer, ed. 1983. Goethe. Écrits sur l'art. [Goethe. Writings on Art]. Paris: Klincksieck. pp. 270-287. [In French].

Le Corbusier, 1953. L'CEuvre Plastique. [The plastic work]. In: W. Boesiger, ed. 1999. Le Corbusier et son atelier rue de Sévres 35. Euvre complète. [Le Corbusier and his studio of Sévres street, 35. Complete Work] Volume 6 - 1952-1957. Berlin: Birkhäuser. pp. 11-15.

Le Corbusier, 1966. Vers une architecture. [Towards an architecture]. Nouvelle ed. revue et augmenteé. Paris: Éditions Vincent, Fréal \& Clo. [In French]

Monestiroli, A., 1993. La arquitectura de la realidad. [The architecture of the reality]. Barcelona: Ediciones del Serbal. [In Spanish]

Rossi, A., 1967. Introduzione a Boullée. [Introduction to Boullée]. In: A. Ferlenga, ed. 2005. Étienne-Louis Boullée. Architettura. Saggio sull'arte. [Étienne-Louis Boullée. Architecture. Essays on art]. Torino: Giulio Einaudi editore. pp. VIIXLIII. [In Italian]

Rossi, A., 1981. A Scientific Autobiography. Cambridge: MIT Press.

Siza, A., 1964. Restaurante junto ao mar, Boa Nova. [Restaurant next to the sea, Boa Nova]. In: C. C. Morais, ed. 2009. Álvaro Siza. 01 Textos. [Álvaro Siza. 01 Texts]. Porto: Civilização Editora. p. 17. [In Portuguese]

Siza, A., 1978. Entretien avec Álvaro Siza. [Interview with Álvaro Siza]. AMC nr.44, Feb. 1978, pp. 33-41. [In French]

Siza, A., 1980a. Interview. L'Architecture d'Aujourd'hui nr.211, Oct. 1980, pp. 1-3. [In French]

Siza, A., 1980b. Piscina de Leça da Palmeira. [Swimming pool at Leça da Palmeira]. In: C. C. Morais, ed. 2009. Álvaro Siza. 01 Textos. [Álvaro Siza. 01 Texts]. Porto: Civilização Editora. pp. 23-24. [In Portuguese]

Siza, A., 1983a. Oito Pontos. [Eight points]. In: C. C. Morais, ed. 2009. Álvaro Siza. 01 Textos. [Álvaro Siza. 01 Texts]. Porto: Civilização Editora. pp. 27-29. [In Portuguese]

Siza, A., 1983b. Alvar Aalto, 3 facetas ao acaso. [Alvar Aalto three random aspects]. Jornal de Letras, Artes e Ideias, Feb. 14 ${ }^{\text {th }}$ 1983, p. 18. [In Portuguese]

Siza, A., 1986. Le Lieu. [The place]. In: F. Ruchat-Roncati, ed. 1986. Álvaro Siza Vieira: Porto: Lisboa: Seminar Woch. Zurich: Eidg. Technische Hochschule. [In French]

Siza, A., 1987. A Villa Savoie revisitada. [Villa Savoie revisited]. In: C. C. Morais, ed. 2009. Álvaro Siza. 01 Textos. [Álvaro Siza. 01 Texts]. Porto: Civilização Editora. pp. 39-42. [In Portuguese]

Siza, A., 1988a. Brasil. [Brazil]. In: C. C. Morais, ed. 2009. Álvaro Siza. 01 Textos. [Álvaro Siza. 01 Texts]. Porto: Civilização Editora. pp. 51-52. [In Portuguese] 
Siza, A., 1988b. Pedem-me para falar do Chiado. [They ask me to talk about Chiado]. In: C. C. Morais, ed. 2009. Álvaro Siza. 01 Textos. [Álvaro Siza. 01 Texts]. Porto: Civilização Editora. pp. 53-54. [In Portuguese]

Siza, A., 1991. Entretien. Comment parvenir à la sérénité. [Interview. How to intervene on serenity]. L'Architecture d'Aujourd'hui nr.278, Dec. 1991, pp. 5865. [In French]

Siza, A., 1992. Prefácio. [Foreword]. In: C. C. Morais, ed. 2009. Álvaro Siza. 01 Textos. [Álvaro Siza. 01 Texts]. Porto: Civilização Editora. p. 109. [In Portuguese]

Siza, A., 1993. Álvaro Siza entrevistado por Matilde Pessanha. [Álvaro Siza interviewed by Matilde Pessanha]. Cadernos ESAP 2/3, Dec. 1997, pp. 8-27. [In Portuguese]

Siza, A., 1995a. Rio de Janeiro. [Rio de Janeiro]. In: C. C. Morais, ed. 2009. Álvaro Siza. 01 Textos. [Álvaro Siza. 01 Texts]. Porto: Civilização Editora. p. 171. [In Portuguese]

Siza, A., 1995b. Palermo é uma das Minhas Cidades. [Palermo is one of My Cities]. In: C. C. Morais, ed. 2009. Álvaro Siza. 01 Textos. [Álvaro Siza. 01 Texts]. Porto: Civilização Editora. pp. 151-154. [In Portuguese]

Siza, A., 1998a. Immaginare l'evidenza. [Imagining evidence]. Roma: Ed. Laterza. [In Italian]

Siza, A., 1998b. Porto. [Porto]. In: C. C. Morais, ed. 2009. Álvaro Siza. 01 Textos. [Álvaro Siza. 01 Texts]. Porto: Civilização Editora. pp. 201-203. [In Portuguese]

Siza, A., 1998c. Alvar Aalto: algumas referências à sua influência em Portugal. [Alvar Aalto: some references on his influence at Portugal]. In: C. C. Morais, ed. 2009. Álvaro Siza. 01 Textos. [Álvaro Siza. 01 Texts]. Porto: Civilização Editora. pp. 211-212. [In Portuguese]

Siza, A., 2005. Um desenho feito em segundos... [A drawing done in seconds...]. In: C. C. Morais, ed. 2009. Álvaro Siza. 01 Textos. [Álvaro Siza. 01 Texts]. Porto: Civilização Editora. p. 329. [In Portuguese]

Weston, R., 1995. Alvar Aalto. London: Phaidon.

Zevi, B., 1950. Towards an organic architecture. London: Faber \& Faber Ltd. 